\title{
FAKTOR RISIKO KEJADIAN ISPA PADA BALITA DI KELURAHAN GADINGREJO KOTA PASURUAN TAHUN 2016
}

\author{
Zenita, Nur Haidah, Sukiran Al Jauhari
}

\begin{abstract}
The proportion of under-five deaths due to pneumonia, according Riskesdas 2007 ranks the second after diarrhea. It is estimated that over 2 million children under five die every year from pneumonia. This study aims to identify risk factors of personal hygiene and home cleaning action with URI incident in children under five in Gadingrejo village, Pasuruan.

This study uses a case control design. The subject of this study were housewives who have children suffering from URI in December 2015 - January 2016. The sample were 40 cases and 40 controls. Sampling was carriedout by Simple Random Sampling. The data collection technique used questionnaire. The collected data was then analyzed by Odd Ratio calculation.

The OR value of personal hygiene with URI was 2.51 and OR value of cleaning action with URI was 2.57. Poor personal hygiene indicated 2.51 times greater risk of a toddler suffering from URI than good personal hygiene. Poor cleaning action also indicated 2.57 times greater risk of a toddler suffering from URI than good house cleaning action.

This study indicates that personal hygiene and home cleaning action is a risk factor of URI in children under five in Gadingrejo village, Pasuruan 2016. Counseling regarding hand washing and house cleaning on a regular basis can increase public knowledge that leads to changes in people's behavior.
\end{abstract}

Keywords : Personal Hygiene, House Cleaning Action, URI

\section{PENDAHULUAN}

Infeksi Saluran Pernapasan Akut (ISPA) adalah penyakit saluran pernapasan atas atau bawah yang biasanya menular yang dapat menimbulkan berbagai spectrum penyakit yang berkisar dari penyakit tanpa gejala atau infeksi ringan sampai penyakit yang parah dan mematikan (WHO, 2007:6). Pneumonia adalah pembunuh utama balita di dunia, lebih banyak dibanding dengan gabungan penyakit AIDS, malaria dan campak. Diperkirakan lebih dari 2 juta balita meninggal karena pneumonia (1 balita/20 detik) per tahunnya dari 9 juta total kematian balita.

ISPA merupakan penyakit yang sering terjadi pada anak. Insidens menurut kelompok umur Balita, diperkirakan 0,29 episode per anak/tahun di negara berkembang dan 0,05 episode per anak/tahun di negara maju (Kemenkes RI, 2011:1). Pada Insiden kasus pneumonia balita nasional tahun 2005-2009, kasus ISPA mengalami penurunan setiap tahunnya hingga pada tahun 2009 Insiden kasus pneumonia sebesar 2,2\% (Kemenkes RI, 2010:1).

Penemuan balita penderita Pneumonia tahun 2014 yang ditangani di Kota Pasuruan sebesar 63,93\% atau 1090 kasus dan ISPA menempati urutan pertama penyakit terbanyak tahun 2014. Dalam periode tahun 2013-2014, ISPA menempati urutan pertama pada 10 besar penyakit di Puskesmas Gadingrejo. Pada tahun
2013, kasus ISPA di Puskesmas Gadingrejo sebesar 2788 kasus dan pada tahun 2014 sebesar 2301 kasus.

Pencegahan penyakit ISPA dapat dilakukan dengan memutus rantai penularan penyakit, dimana rantai penularan penyakit meliputi host (penjamu), agent (penyebab) dan environment (lingkungan). Sehingga pencegahan dapat dilakukan dengan cara menghentikan kontak agent penyebab penyakit dengan penjamu. Faktor pencegahan penularan menitikberatkan pada penanggulangan faktor risiko penyakit seperti lingkungan dan perilaku (Sundari dkk, 2014:2).

Perilaku sehat merupakan perilaku proaktif guna memelihara dan meningkatkan kesehatan, mencegah risiko terjadinya penyakit serta melindungi diri dari ancaman penyakit (UNICEF, 2010). Faktor yang pempengaruhi perilaku kesehatan menurut teori Lawrence Green (1980), kesehatan seseorang atau masyarakat dipengaruhi oleh 2 faktor perilaku pokok, yaitu faktor perilaku (behavior causes) dan faktor diluar perilaku (non behavior cause). Perilaku itu ditentukan atau terbentuk dari 3 faktor, yaitu faktor predisposisi (predisposing factors), yaitu terwujud dalam pengetahuan, sikap, kepercayaan, keyakinan, niali-nilai, dan sebagainya. Faktor-faktor pendukung (enabling factors), yang terwujud dalam lingkungan fisik, tersedianya fasilitas-fasilitas atau sarana-sarana 
yang diperlukan. Misalnya puskesmas, obat-obat, air bersih dll. Faktor-faktor pendorong (reinforcing faktor) yang terwujud dalam sikap dan perilaku petugas kesehatan atau petugas lainnya, yang merupakan kelompok referensi dari perilaku masyarakat (Notoatmodjo, 2010:20-23 ).

Penelitian ini bertujuan untuk mengetahui faktor risiko higiene perorangan dan tindakan pembersihan rumah dengan kejadian ISPA pada balita di Kelurahan Gadingrejo Kota Pasuruan.

\section{METODE PENELITIAN}

Penelitian ini merupakan studi epidemiologi analitik dengan pendekatan case control yaitu suatu penelitian analitik yang digunakan untuk menyelidiki orang-orang yang menderita penyakit atau efek (kasus) yang hendak diselidiki penyebabnya (faktor risiko) dibandingkan dengan orang-orang yang tidak menderita penyakit atau efek tersebut (kontrol) yang dilakukan secara retrospektif. (Budiman, 2011:119)

Populasi penelitian ini adalah seluruh ibu rumah tangga yang setiap harinya mengurusi rumah tangga dan memiliki balita yang dinyatakan menderita ISPA pada bulan Desember 2015 - Januari 2016 yang berdomisili di Kelurahan Gadingrejo Kota Pasuruan. Besar

sampel penelitian adalah 80 orang. Sampel penelitian kelompok kasus adalah ibu rumah tangga yang memiliki balita penderita ISPA yang diperiksa di Puskesmas Gadingrejo pada bulan Desember 2015 - Januari 2016 sebanyak 40 orang dan kelompok kontrol adalah ibu rumah tangga yang memiliki balita bukan penderita ISPA di wilayah Kelurahan Gadingrejo Kota Pasuruan sebanyak 40 orang. Variabel penelitian meliputi variabel independen yaitu higiene perorangan dan tindakan pembersihan rumah

Analisis dilakukan dengan menghitung Odds Ratio ysng menyatakan besarnya resiko untuk menderita bagi mereka yang terpapar. Kriteria hasil analisis, apabila (a) nilai $O R=1$ artinya tidak ada hubungan antara faktor risiko dengan kejadian penyakit ISPA pada balita, (b) nilai $\mathrm{OR}<1$ artinya faktor risiko tersebut mempunyai pengaruh pencegahan terhadap terjadinya penyakit ISPA pada balita, (c) nilai OR $>1$ artinya faktor risiko tersebut mempunyai pengaruh penyebab terhadap terjadinya penyakit ISPA pada balita.

\section{HASIL DAN PEMBAHASAN}

Usia balita, higiene perorangan ibu dalam merawat balita dan tindakan pembersihan rumah oleh ibu di Kelurahan Gadingrejo Kota Pasuruan digambarkan seperti dalam Tabel 1,2,3.

Tabel 1

Distribusi Frekuensi Balita Berdasarkan Usia

\begin{tabular}{ccccc}
\hline \multirow{2}{*}{ No. } & \multirow{2}{*}{ Golongan Usia } & $\mathrm{N}$ & Jumlah \\
\cline { 3 - 4 } & & & 14 & $\%$ \\
\hline 1. & $<1$ Tahun & 66 & 17.5 \\
\hline 2. & $1-5$ Tahun & & 80 & 82.5 \\
\hline & Total & 100 \\
\hline
\end{tabular}

Tabel 2

Distribusi Frekuensi Responden Berdasarkan Tingkat Higiene Perorangan

\begin{tabular}{lllll}
\hline \multirow{2}{*}{ No. } & \multirow{2}{*}{ Higiene Perorangan } & \multicolumn{2}{c}{ Jumlah } \\
\cline { 3 - 5 } & & Kurang Baik & 43 & $\%$ \\
\hline 1. & Baik & & 37 & 53.8 \\
\hline \multicolumn{2}{r}{} & Total & 80 & 46.3 \\
\hline
\end{tabular}

Tabel 3

Distribusi Frekuensi Responden Berdasarkan Tindakan Pembersihan Rumah

\begin{tabular}{ccccc}
\hline \multirow{2}{*}{ No } & \multirow{2}{*}{ Tindakan Pembersihan } & \multicolumn{2}{c}{ Jumlah } \\
\cline { 3 - 4 } & & Kurang Baik & 33 & $\%$ \\
\hline 1. & Baik & & 47 & 51,3 \\
\hline & & Total & 80 & 100 \\
\hline
\end{tabular}

Usia balita paling banyak di kelurahan Gadingrejo yaitu 1- 5 tahun. Frekuensi higiene perorangan ibu dalam merawat balita adalah ibu yang memiliki higiene perorangan kurang baik lebih banyak dibandingkan ibu yang mempunyai higiene perorangan baik. Tindakan pembersihan rumah oleh ibu paling banyak ibu memiliki tindakan pembersihan rumah baik 
Tabel 4

Analisis Risiko Higiene Perorangan Dengan Kejadian ISPA

\begin{tabular}{|c|c|c|c|c|}
\hline \multirow{2}{*}{ No } & \multirow[b]{2}{*}{ Higiene Perorangan } & \multicolumn{2}{|c|}{ Kejadian ISPA } & \multirow[b]{2}{*}{ Total } \\
\hline & & ISPA (\%) & Tidak ISPA (\%) & \\
\hline 1. & Kurang Baik & $\begin{array}{c}26 \\
(32,5 \%)\end{array}$ & $\begin{array}{c}17 \\
(21,2 \%)\end{array}$ & $\begin{array}{c}43 \\
(53,8 \%)\end{array}$ \\
\hline 2. & Baik & $\begin{array}{c}14 \\
(17,5 \%)\end{array}$ & $\begin{array}{c}23 \\
(28,8 \%)\end{array}$ & $\begin{array}{c}37 \\
(46,2 \%)\end{array}$ \\
\hline \multicolumn{2}{|r|}{ Total } & $\begin{array}{c}40 \\
(50 \%)\end{array}$ & $\begin{array}{c}40 \\
(50 \%)\end{array}$ & $\begin{array}{c}80 \\
(100 \%)\end{array}$ \\
\hline \multicolumn{5}{|c|}{$\begin{array}{c}\text { Tabel } 5 \\
\text { Analisis Risiko Tindakan Pembersihan Rumah Dengan Kejadian ISPA }\end{array}$} \\
\hline \multirow{2}{*}{ No } & \multirow{2}{*}{$\begin{array}{l}\text { Tindakan Pember- } \\
\text { sihan }\end{array}$} & \multicolumn{2}{|c|}{ Kejadian ISPA } & \multirow{2}{*}{ Total } \\
\hline & & ISPA (\%) & Tidak ISPA (\%) & \\
\hline 1. & Kurang Baik & $\begin{array}{c}21 \\
(26,2 \%)\end{array}$ & $\begin{array}{c}12 \\
(15 \%)\end{array}$ & $\begin{array}{c}33 \\
(41,2 \%) \\
\end{array}$ \\
\hline 2. & Baik & $\begin{array}{c}19 \\
(23,8 \%)\end{array}$ & $\begin{array}{c}28 \\
(35 \%)\end{array}$ & $\begin{array}{c}47 \\
(58,8 \%)\end{array}$ \\
\hline & Total & $\begin{array}{c}40 \\
(50 \%)\end{array}$ & $\begin{array}{c}40 \\
(50 \%)\end{array}$ & $\begin{array}{c}80 \\
(100 \%)\end{array}$ \\
\hline
\end{tabular}

Analisis resiko pada variabel higiene perorangan dan tindakan pembersihan rumah menunjukkan bahwa pada tabel 4 ibu rumah tangga banyak yang memiliki higiene perorangan kurang baik dan memiliki balita penderita ISPA. Hasil perhitungan OR didapatkan nilai OR sebesar 2,51, mengartikan bahwa higiene perorangan merupakan faktor risiko terjadinya ISPA. Analisis tindakan pembersihan rumah oleh ibu menunjukkan bahwa ibu banyak yang memiliki tindakan pembersihan rumah baik dan memiliki balita tidak menderita ISPA. Hasil perhitungan OR didapatkan nilai OR sebesar 2,57 mengartikan bahwa tindakan pembersihan rumah merupakan faktor risiko terjadinya ISPA.

Kebersihan merupakan hal penting yang harus diperhatikan karena kebersihan akan mempengaruhi kesehatan, kenyamanan, keamanan dan kesejahteraan klien (Isro'in, Laily. 2012). Higiene perorangan atau kebersihan perorangan merupakan tindakan memelihara kebersihan dan kesehatan seseorang, baik fisik dan psikisnya. Kebersihan diri atau higiene perorangan meliputi perawatan kulit kepala dan rambut, perawatan mata, hidung, telinga, kuku tangan dan kaki, genitalia, kulit seluruh tubuh dan perawatan tubuh secara keseluruhan (Tarwoto \& Wartonah 2006 dalam Israfil et al, 2013).

Kebersihan sangat diperlukan untuk mencegah infeksi penyakit, salah satunya melalui cuci tangan dan menjaga kebersihan pakaian. Kebiasaan mencuci tangan dengan sabun dan air mengalir dapat menghindarkan kita dari penyakit, salah satunya adalah infeksi saluran pernapasan seperti pneumonia. Hidung balita penderita ISPA mengandung mucus yang merupakan media tempat pertumbuhan dan perkembangbiakan mikroorganisme penyebab ISPA, oleh karena itu bentuk perawatan hidung, kuku dan tangan untuk mencegah penyakit ISPA yaitu dengan mencuci tangan sehingga bibit penyakit akan mati dan akan menghilangkan kotoran yang akan masuk ke makanan atau mulut.

Perilaku tidak sehat ibu khususnya mengenai higiene perorangan dalam penelitian ini meliputi kebiasaan ibu mencuci tangan sebelum dan sesudah makan, ketika menyusui, saat batuk maupun terkena cairan hidung, perilaku ibu memotong kuku, keteraturan mandi,dan tindakan mencuci tangan balita sesudah bermain. Hasil analisis risiko dengan menghitung nilai Odds Ratio diperoleh nilai Odds Ratio sebesar 2,51 yang berarti higiene perorangan menjadi faktor risiko kejadian ISPA balita. Responden dengan higiene perorangan kurang baik memiliki risiko 2,51 kali lebih besar memiliki Balita menderita ISPA dibandingkan dengan responden yang mempunyai higiene perorangan baik. Penelitian Tri Yoga, 2015 menyatakan perilaku mencuci tangan buruk mempunyai risiko mengalami ISPA berulang 6,55 kali lebih besar dibanding dengan keluarga yang memiliki perilaku cuci tangan baik.

Higiene perorangan khususnya cuci tangan dengan sabun merupakan cara pencegahan yang penting, dimana dengan mencuci tangan dengan sabun akan menurunkan jumlah mikroorganisme pada tangan guna untuk mencegah penyebaran penyakit diare, ISPA, Flu Burung. Pemberian pendidikan kesehatan guna menurunkan angka kejadian ISPA dapat dilakukan melalui penyuluhan higiene peroranagan oleh tenaga kesehatan perlu dilakukan pada kegiatan sekolah, kelompok ibu pengajian dan kelompok ibu PKK, guna meningkatkan pengetahuan ibu dan anak mengenai higiene perorangan khususnya cuci tangan sehingga perilaku 
masyarakat khususnya orang tua mengenai kebersihan tangan, hidung dan kuku akan lebih baik

Menurut WHO, Rumah merupakan suatu struktur fisik yang dipakai manusia sebagai tempat berlindung, dimana kondisi lingkungan rumah tersebut akan berhubungan dengan kesehatan fisik dan rohani bagi anggota keluarga.Kebersihan rumah merupakan salah satu upaya kesehatan guna mencegah terjadinya penyakit di dalam rumah. Tindakan pembersihan rumah dapat dilakukan dengan membersihkan lantai dan perabotan rumah dari kotoran dan debu secara teratur, serta merapikan perabotan yang ada dirumah (Kemenkes RI, 2010:130). membuka jendela sehingga pemenuhan udara dalam rumah tidak terpenuhi. Hasil analisis risiko dengan perhitungan nilai Odds Ratio diperoleh nilai Odds Ratio sebesar 2,57 yang berarti tindakan pembersihan rumah menjadi faktor risiko kejadian ISPA balita. Responden dengan tindakan pembersihan rumah kurang baik memiliki risiko 2,57 kali lebih besar memiliki Balita menderita ISPA dibandingkan dengan responden yang mempunyai tindakan pembersihan rumah baik.

Penelitian Nani Rusdawati, 2012 menyebutkan bahwa perilaku keluarga yang perlu mendapatkan perhatian khusus salah satu nya adalah membuka jendela dan pintu, membersihkan rumah, menjemur bantal dan kasur. Dimana perilaku keluarga yang kurang

\section{KESIMPULAN DAN SARAN}

Karakteristik balita di Kelurahan Gadingrejo lebih banyak berusia 1-5 tahun dari pada balita 0-1 tahun. Higiene perorangan menunjukkan bahwa 53,8\% responden memiliki higiene perorangan kurang baik dan tindakan pembersihan rumah menunjukkan bahwa $58,8 \%$ responden memiliki tindakan pembersihan rumah baik. Hasil analisis menggunakan perhitungan Odds Ratio, didapatkan hasil bahwa higiene perorangan merupakan faktor risiko dari kejadian ISPA di Kelurahan Gadingrejo Kota Pasuruan Tahun 2016 dengan OR sebesar 2,51

\section{DAFTAR PUSTAKA}

Catiyas, Embriyowati, 2012. Faktor-Faktor Yang Berhubungan Dengan Kejadian ISPA Pada Balita Di Wilayah Kecamatan Gombong Kabupaten Kebumen Jawa Tengan Tahun 2012 (Skripsi). Depok. Universitas Indonesia.

Dinkes, 2013. Profil Kesehatan Provinsi Jawa Timur Tahun 2012. Surabaya, Dinas Kesehatan Provinsi Jawa Timur

Ebrahim. M. D, 1994. Perawatan Anak. Yogyakarta, Buku-buku Ilmiah Kedokteran. Cetakan Keempat

Israfil, et all., 2013. Analisis Faktor Yang Berhubungan Dengan Kejadian ISPA Pada
Mengutip dari Retno Widyaningtyas yang menyatakan bahwa keadaan lantai yang berdebu merupakan salah satu bentuk polusi udara dalam rumah. Debu dalam udara bila terhirup akan menempel pada saluran napas bagian bawah. Akumulasi tersebut akan menyebabkan elastisitas paru menurun sehingga menyebabkan anak balita sulit bernapas (Santila, 2010:23).

Observasi di tempat penelitian menunjukkan masih banyak ibu yang mempunyai tindakan pembersihan kurang yang ditandai dengan perabotan rumah dalam keadaan kotor dan tidak tertata, lantai rumah yang kotor karena pembersihan tidak dilakukan secara rutin, serta kebiasaan tidak baik tersebut akan berisiko menyebabkan penyakit ISPA sebesar 3,38 kali lebih besar dibandingkan balita dengan perilaku keluarga baik.

Pencegah ISPA dapat dilakukan dengan menjaga kebersihan dan kesehatan lingkungan rumah dengan mengatur ventilasi dengan baik, menjaga lantai dan perabotan selalu bersih, membuka jendela pada siang hari untuk memperoleh udara segar, serta pencahayaan alami (sinar matahari dapat membunuh bakteri atau kuman secara langsung). Hal ini dapat terwujud melalui peran tenaga kesehatan maupun pemerintah dengan program penyuluhan ataupun program kerja bakti untuk menjaga kebersihan dan kesehatan lingkungan rumah.

dan tindakan pembersihan rumah juga merupakan faktor risiko dari kejadian ISPA di Kelurahan Gadingrejo Kota Pasuruan Tahun 2016 dengan OR sebesar 2,57.

Hasil penelitian ini diharapkan dapat digunakan sebagai masukkan materi promosi kesehatan dalam pencegahan dan pengendalian ISPA pada balita melalui program penyuluhan maupun program karya bakti guna meningkatkan perilaku masyarakat mengenai penting higiene perorangan dan tindakan pembersihan rumah

Balita Berdasarkan Pendekatan Teori Florence Nightingale Di Wilayah Kerja Puskesmas Alak Kupang NTT (Jurnal). Surabaya, Universitas Airlangga

Kementerian Kesehatan RI, 2011. Pedoman Pengendalian Infeksi Saluran Pernapasan Akut. Jakarta, Kementerian Kesehatan RI

Kementerian Kesehatan RI, 2010. Pneumonia Balita Buletin Jendela Epidemiologi. Jakarta. Kementerian Kesehatan RI

Kusumawati, Ita, 2010. Hubungan Antara Status Merokok Anggota Keluarga Dengan Lama Pengobatan ISPA Balita Di Kecamatan 
Jenawi (Tesis). Surakarta, Universitas Sebelas Maret

Notoatmojo, Soekidjo, 2005. Metodelogi Penelitian Kesehatan. Jakarta, Rineka Cipta

Hasan, R, N, 2012. Faktor-Faktor Yang Berhubungan Dengan Kejadian ISPA Pada Balita Di Wilayah Kerja Uptd Kesehatan Luwuk Timur Kabupaten Banggai Provinsi Sulawesi Tengah Tahun 2012 (Skripsi). Depok, Universitas Indonesia

Soedarto,2013. Lingkungan dan Kesehatan Environment and Health. Jakarta, Sagung Seto

Sundari, Siti, 2014. Perilaku Tidak Sehat Ibu Yang Menjadi Faktor Resiko Terjadinya ISPA Pneumonia Pada Balita, Jurnal Pendidikan Sains. 2(3)

Surudji, Didik, 2006. Kesehatan Lingkungan. Sidoarjo, Media IImu
Suyono dan Budiman, 2012. IImu Kesehatan Masyarakat Dalam Konteks Kesehatan Lingkungan. Jakarta, Buku

Kedokteran EGC

WHO, 2007. Pencegahan Dan Pengendalian Infeksi Saluran Pernapasan Akut (ISPA) Yang Cenderung Menjadi Epidemic Dan Pandemic Di Fasilitas Pelayanan Kesehatan. Jenewa, WHO/HSE/EPR/2008.2

Widoyoko, E.P., 2014. Teknik Penyusunan Instrumen Penelitian. Yogyakarta, Pustaka Belajar. Cetakan Ketiga

Yoga, Tri, 2015. Analisis Faktor Perilaku Hidup Bersih Dan Sehat (Phbs) Dengan Kejadian Penyakit ISPA Berulang Pada Balita Di Wilayah Kerja Puskesmas Pekalongan Selatan Kota Pekalongan (Skripsi). Semarang. Universitas Negeri Semarang. 